\title{
Disposal Pattern of Cattle Calves Born through Embryo Transfer Technology
}

\author{
Vaishali Sah, R.K. Tonk, Ravinder Kumar, B.R. Yadav* \\ Livestock Genome Analysis Laboratory, Dairy Cattle Breeding Division, National Dairy Research Institute, \\ Karnal, Haryana, Karnal - 132001, Haryana, India
}

\begin{abstract}
*Corresponding Author: B.R. Yadav, Livestock Genome Analysis Laboratory, Dairy Cattle Breeding Division, National Dairy Research Institute, Karnal, Haryana, Email ID: bry.ndri@gmail.com Mb: 918950927007
\end{abstract}

\begin{abstract}
The study was carried out on the fate of 69 calves (37 males and 32 females) of cattle born through embryo transfer technology (ETT) during 2002-2005. Among these two sets were of twins, both Sahiwal. The calves were of both sexes from two prime milch breeds: Sahiwal (Sw: 21) and Karan Fries (KF: 48) maintained in an organized herd. The data was analyzed from birth to their stay in herd, as a few (4) animals up to the age of 10 years (2015). The disposal of both males and females of different age groups namely up to 1 month, 1-12 months, 1-3 years, 3-5 years 5-7 years and 7-10 years was 17.39, 13.04, 8.70, 33.33, 21.74 and 5.80 percent, respectively. The disposal at young age from birth to three years was mostly due to death 24 $(34.78 \%)$ and other $3(4.35 \%)$.were auctioned as poor health and a freemartin. Survival beyond three years of age among females was 16 (50\%), these conceived and gave birth to progeny. However, these were later on disposed due to death (3) and auction (13). In the males 26(70.27\%) survived beyond three years and entered 'age of first ejaculation (AFE)' but were disposed at various stages of training and use due to poor libido or poor semen quality or freezability. Out of total males only 2 remained in the herd and produced progeny, with suspected chromosomal defect and hence were maintained as experimental. The disposal from birth up to 5 years of age was found to be $65.63 \%$ females and $78.38 \%$ males; subsequently it was overall up to 7 years $87.5 \%$ females and $100 \%$ males. Only 4 cows stayed beyond seven years, calved 4-7 times, however, got endometritis infection and were disposed. This study showed that the ET born calves died or disposed due to involuntary culling without contribution to herd and hence the technique requires high attention before adoption in India.
\end{abstract}

Keywords: Disposal pattern, ETT, culling, embryo, Sahiwal, Karan Fires

\section{INTRODUCTION}

In dairy animals breeding herds the practice of culling and mortality together constitute disposal pattern. Culling is the removal of undesirable animals from the herd to facilitate the entry of replacement by better heifers for improving the herd performance or to keep the herd size constant. The removal of animals from the herd is either voluntary on the basis of low production or involuntary for the reasons such as poor growth and various reproductive problems or health disorders. Exclusion of less productive animals from the herd is likely to bring genetic improvement in the progeny, but substantial removal by involuntary culling or early death hamper the genetic progress in any breeding programme. Moreover, these losses reduce the opportunity for selection of more desirable animals.

The emergence and development of modern reproductive techniques and their applications have given a big boost to the economic gain offered by the increase in the number of desired progenies from superior individuals and a tool to make effective use of genetic merit of infertile or sub-fertile animals ${ }^{1}$. Currently assisted reproductive technologies (ARTs) and various biotechnologies have provided new ways to breeders and animal geneticists to design, direct and alter the reproductive course, inculcate desired traits and accelerate genetic improvement. The well-known ARTs include artificial insemination (AI), embryo biotechnology (ET), multiple ovulation and embryo transfer 
(MOET), in vitro embryo production (IVEP) using in vitro maturation (IVM), fertilization (IVF) and culture (IVC), sex sorting and somatic cell cloning by nuclear transfer (SCNT), transgenesis, sperm sexing or sorting or separation of X- and Y-bearing spermatozoa.

The biotechnological developments up to the end of the $20^{\text {th }}$ century made embryo transfer technology (ETT) commercially feasible in developed countries as a large international business in breeding several animal species ${ }^{2}$. The aim of this technique has always remained in focus to improve the genetic progress of the herds, multiply and utilize the merit of the superior animals. The adoption of ARTs including ETT was also started in India at several places by many organizations including NDRI, Karnal. Progenies have been born in different species; however, many suffered with one or the other ailment and technology remained confined to sporadic places or mostly as experimental research activity. Hence an emphasis must be given on refinement in adoption of technology and precaution while production of such offspring their fate is also to be foreseen. In this institute, where this study was conducted and progenies were produced for a considerable duration. The present report pertains to these calves, their stayability in the herd and disposal.

\section{MATERIALS AND METHODS}

The study was carried out on 69 calves of both sexes (37 males and 32 females) born using embryo transfer technology (ETT) in two milch breeds of cattle comprising of Sahiwal (21) and Karan Fries (48) at NDRI, Karnal during 2002-2005. Among these two sets were of twins (both in Sahiwal): one was heterosexual and the other was isosexual males. The records of calves were searched from different types of registers maintained at cattle yard. Information was gathered for their disposal from birth up to survival or stay and performance in the herd. For the sake of study the whole period was broadly classified in six different age groups as given in table- 1 . These were group I ( 0 - 1 month), II (1-12 months), III (1- 3 yrs.), IV (3-5 yrs.), V (5-7yrs.) and VI (7-10 yrs.), respectively. The last group had 4 females conceived, calved, stayed long in the herd and produced just like contemporaries born using AI as routine. The number of males and females removed from the herd by culling as well as death were counted separately and the overall disposal rate was expressed in percentage for all the groups.

Table1. Disposal pattern and stayability of ET born calves in an organized herd

\begin{tabular}{|c|c|c|c|c|c|c|c|c|c|c|c|c|c|}
\hline \multirow{2}{*}{\multicolumn{2}{|c|}{$\begin{array}{l}\text { Types of } \\
\text { animals }\end{array}$}} & \multicolumn{12}{|c|}{ Age ofdisposal andnumber of individuals } \\
\hline & & \multicolumn{2}{|c|}{ 0-1 Month } & \multicolumn{2}{|c|}{$\begin{array}{l}1-12 \\
\text { Months }\end{array}$} & \multicolumn{2}{|c|}{$1-3$ Years } & \multicolumn{2}{|c|}{ 3-5 Years } & \multicolumn{2}{|c|}{ 5-7 Years } & \multicolumn{2}{|c|}{ 7-10 Years } \\
\hline \multicolumn{2}{|c|}{ Females } & \multicolumn{2}{|c|}{7} & \multicolumn{2}{|c|}{4} & \multicolumn{2}{|c|}{5} & \multicolumn{2}{|c|}{5} & \multicolumn{2}{|c|}{7} & \multicolumn{2}{|c|}{4} \\
\hline $\begin{array}{c}\text { Sw: } \\
7\end{array}$ & $\begin{array}{c}\text { KF: } \\
25\end{array}$ & $\begin{array}{c}\text { Sw: } \\
2\end{array}$ & $\begin{array}{c}\text { KF: } \\
5\end{array}$ & $\begin{array}{c}\text { Sw: } \\
1\end{array}$ & $\begin{array}{c}\text { KF: } \\
3\end{array}$ & $\begin{array}{l}\text { Sw: } \\
2^{*}\end{array}$ & $\begin{array}{c}\text { KF: } \\
3\end{array}$ & $\begin{array}{c}\text { Sw: } \\
1\end{array}$ & $\begin{array}{c}\text { KF: } \\
4\end{array}$ & $\begin{array}{c}\text { Sw: } \\
1\end{array}$ & $\begin{array}{c}\text { KF: } \\
6\end{array}$ & $\begin{array}{l}\text { Sw: } \\
-\end{array}$ & $\begin{array}{c}\text { KF: } \\
4\end{array}$ \\
\hline \multicolumn{2}{|c|}{ Males } & \multicolumn{2}{|c|}{$\frac{1}{5}$} & \multicolumn{2}{|c|}{5} & \multicolumn{2}{|c|}{1} & \multicolumn{2}{|c|}{18} & \multicolumn{2}{|c|}{8} & \multicolumn{2}{|r|}{ 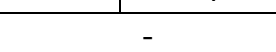 } \\
\hline $\begin{array}{c}\text { Sw: } \\
12\end{array}$ & $\begin{array}{c}\text { KF: } \\
25\end{array}$ & $\begin{array}{c}\text { Sw: } \\
2\end{array}$ & $\begin{array}{c}\text { KF: } \\
3\end{array}$ & $\begin{array}{l}\text { Sw: } \\
3\end{array}$ & $\begin{array}{c}\text { KF: } \\
2\end{array}$ & Sw: & KF: & $\begin{array}{l}\text { Sw: } \\
5\end{array}$ & $\begin{array}{c}\text { KF: } \\
13\end{array}$ & $\begin{array}{l}\text { Sw: } \\
2 *\end{array}$ & $\begin{array}{c}\text { KF: } \\
6\end{array}$ & Sw: & KF: \\
\hline \multicolumn{2}{|c|}{ Per cent } & \multicolumn{2}{|c|}{17.39} & \multicolumn{2}{|c|}{13.04} & \multicolumn{2}{|c|}{8.70} & \multicolumn{2}{|c|}{33.33} & \multicolumn{2}{|c|}{21.74} & \multicolumn{2}{|c|}{5.80} \\
\hline \multicolumn{2}{|c|}{$\begin{array}{l}\text { Reasons } \\
\text { of } \\
\text { disposal / } \\
\text { culling }\end{array}$} & \multicolumn{2}{|c|}{ 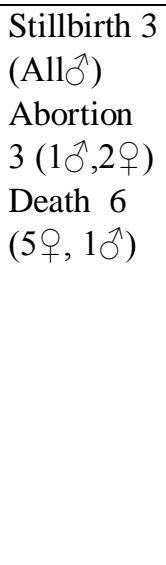 } & \multicolumn{2}{|c|}{$\begin{array}{l}\text { Death } 8 \\
\left(4 \circ, 4{ }^{\lambda}\right), \\
\text { Auction } 1 \\
\left(1 \delta^{\wedge}: \text { Poor }\right. \\
\text { health) }\end{array}$} & \multicolumn{2}{|c|}{$\begin{array}{l}\text { Death } 4 \\
\left(3 \text { + }, 1 \delta^{\lambda}\right) \\
\text { Auction } 2 \\
(1 \text { 우 Poor } \\
\text { health+1*) } \\
\text { *Freemartin }\end{array}$} & \multicolumn{2}{|c|}{$\begin{array}{l}\text { Auction: } \\
\text { Females } \\
\left(5^{\dagger}\right) ; \text { Males } \\
\left(18^{\S}\right)\end{array}$} & \multicolumn{2}{|c|}{ 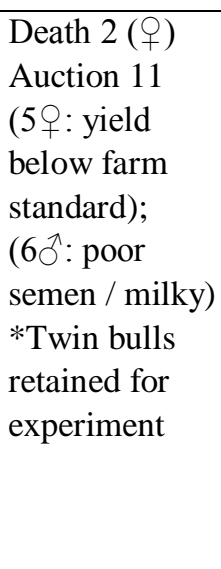 } & \multicolumn{2}{|c|}{$\begin{array}{l}\text { Death } 1^{\mathbf{a}}(+) \\
\text { Auction } 3^{\mathbf{b}}(+) \\
{ }^{\mathbf{b}} \text { Healthproblem: in } \\
\text { lactations/ calving: } \\
7^{\text {th }}-1 \text { (Chronic } \\
\text { Endometritis), } \\
\text { Stayed 3 years as } \\
\text { dry } \\
6^{\text {th }} \text {-Calving -2 } \\
\text { (Stillbirth- } 1^{\text {a } \&} \\
\text { Endometritis-1) } \\
4^{\text {th }}-1 \\
\text { (Endometritis) }\end{array}$} \\
\hline
\end{tabular}

Reasons of Auction: 'Poor health \& lame (2), repeat breeder (1), fibrosis in reproductive organs (1), stillbirth (2), Endometritis (4) and yield below farm standard (6); ${ }^{\$}$ Surplus (6), body defects (5), poor libido (2), poor quality semen (3), poor freezability of semen (2), experimental observations (2) 


\section{RESULTS AND DISCUSSION}

The information collected for all the 69 ET born calves was scrutinized critically on the basis of their survival and stay in herd and disposal pattern was calculated as presented in table-1.It was found that mortality was $17.39 \%$ within one month of age. This comprised of 5 males and 7 females. Among these two deaths were due to pneumonia and others were either stillbirth or abortions. Many of those survived were weak and debilitated and died at later stages. Subsequent to post one month age, the disposal was $13.04 \%$ between 1 - 12months; out of which $89 \%$ (8/9) died (reasons not recorded) and rest $11 \%$ (1/9) auctioned. During the period 1-3 years $8.7 \%$ were disposed, among these four died, while one was disposed being weak and the one as was freemartin. Further observations showed that $33.33 \%$ animals were disposed by public auction during 3-5 years of age. The main reason was involuntary culling and was similar in both sexes. Subsequently during 5-7 years of age was $21.74 \%$ were disposed due to death ( 2 females) and others in public auction. In the end the last group 4 cows $(5.80 \%)$ remained in the herd for longer duration of 7-10 years, completed 4-7 lactations, however got infected with endometritis and were disposed due to death (1) and auction (3).

In the ETT programme at NDRI selected better cows were used and hence attempt was also made to assess the performance of their calves, which showed 26males and 16females reached their puberty age and breeding stage. The record of these animals was examined systematically for their reproductive performance and disposal. The reasons of all these has been given in the last row of the table-1. In the male set18 were disposed during 3-5 years of age reasons as body defects (5), poor libido (2), semen quality poor (3), non-freezability of semen (2) and surplus (6). The 8 remaining males were given further training and semen was collected, however, 6 produced poor quality milky semen, and were disposed. Nevertheless, 2 bulls (born isosexual twin) produced acceptable quality semen and were retained for experimentation purpose. Chromosome evaluations showed translocation in both these bull and they transmitted to their progeny and were removed from breeding programme. In the female lot 5 were disposed during 3-5 years of age, reasons due to poor health-lameness (1), repeat breeder (1), fibrosis in reproductive organs (1), and those (2) conceived and produced milk were below farm standard. Further during 5-7 years age 2 females died and 5 failed to reach to the level of standard yield in the farm, hence were auctioned. Thus only 4 remained in the herd beyond 9 years and well comparable to farm standard. However, among these 1 died after giving stillbirth calf, remaining 3 got infected with endometritis and were disposed in public auction.

In the study the herd life and performance of twins was also like other ET calves. In the heterosexual set male died within one month and female was disposed at puberty age on failing to enter estrous cycle as turned out freemartin, chromosome chimaerism $(60, \mathrm{XX} / 60, \mathrm{XY})$ was observed. The isosexual males became bulls, donated semen; however performance was poor, both had abnormal chromosomes (autosomal translocation) and were kept for experimental observation. The examination of 7 physically available animals revealed 3 with chromosome anomaly. This investigation showed all the 69 ET calves were disposed due to death or culling without desired contribution to the herd.

During the period of Mahabharata (epic) all the modern ARTs were practiced, however, most of the individuals born through these means caused damage to the then society are well known for their evils. In the modern era several ARTs have been applied in humans to overcome subfertility problems $^{3.4}$ and in many other species including dairy animals to accelerate genetic gain and multiply superior individuals ${ }^{5}$. In cattle beef breeds the technology has proved quite economical ${ }^{6}$; however in general cattle breeding programmes these have been used to produce progeny though with some mortality ${ }^{7}$.In India including this institute (NDRI) by the application of these techniques using huge expenditure a few animals have been produced though had high birth weight and poor stayability, which makes their genetic evaluation mandatory.

In the western countries several studies on ETT have been carried out to evaluate the effect of altered environment that embryos receive during flushing, handling, storage and further transfer to the recipient $^{2,8,9}$. Some epigenetic mechanisms have been suggested responsible besides chromosomal anomalies that accounted for 7-10\% of the embryonic losses ${ }^{10}$. The well-known phenomenon of dosage compensation (inactivation of one of the X-chromosomes) in females involves a cascade of chromatin remodelling events; however, during in vitro handling of embryos it gets altered, which has been reported as lethal to the embryos resulting in their loss ${ }^{11}$. 
Similar to conventional disposal of animals there could be various reasons for ET born calves, nevertheless chromosomal defects tend to decide viability and also their reproductive and productive performance.In an earlier study on day-2 or -3 embryos flushed from Clun and Herdwick ewes treated with pregnant mares serum gonadotrophin (PMSG)chromosomally abnormal have reported as 20 and $9 \%$, repectively ${ }^{12}$.In another study high level of FSH has been found to induce aneuploidy ${ }^{13}$. The uterus provides the nurturing environment that supports the growth of the early preimplantation bovine conceptus. Any disturbance during this period is bound to hinder the growth and development characteristics of the ET calves. Major differences between asynchronous and synchronous transfer of embryo have been documented in terms of foetal size ${ }^{14}$. This defect leads to dystocia and result in still births or abortions. The embryo transfer (ET) has been a quite popular technology, however, has a limitation due to large offspring syndrome (LOS) and other problems. The LOS has been shown in bovine calves produced by exposing embryos to unusual environments both in vivo and in vitro ${ }^{14}$, ${ }^{15}$.Embryo culture, asynchronous transfer into advanced uterine environment and maternal exposure to excessively high urea diets have also been shown as the causal factors of $\operatorname{LOS}^{16}$. The problem of large size of progeny has also been associated with increased prenatal losses and other physiological malfunctions. Thus evaluation of embryos or early conceptuses essential to avoid cytogenetical, epigenetic and physiological malfunctions in the new born calves. Cytogenetic anomalies such as mixoploidy, polyploidy and structural rearrangements have been reported in ET produced calves ${ }^{17}$.

The majority of embryos losses in cattle occur because of genetic abnormalities have been suggested long back in humans ${ }^{18}$. The abnormal embryos are eliminated early in their life. The role of chromosomal abnormalities has also been reported as one of the main cause of the embryonic losses in domestic animals ${ }^{10}$. In ET technique during in vitro manipulation of gametes and embryos, various forms of hazards might be causing damage easily to the cells, as they are under artificial conditions that can lead to different problems in the coming progeny ${ }^{19}$. Mortality in terms of embryonal and foetal losses is a major reason of disposal pattern.

In order to compare with conventional programme of breeding animals, literature scanning revealed similar reasons of culling on body defects and reproductive problems ${ }^{20,21,22,23}$. In cows the main reasons for disposal is related to udder problems and below farm standards.Various subfertility traits like poor libido and unacceptable seminal profile were found to be the significant reasons $(p<0.01)$ for culling of the breeding bull. In the same herd of this study on AI born bulls inadequate sex drive was the main contributing factor for disposal in Sahiwal (22.55\%) and Murrah bulls (15.12\%) whereas poor semen quality and freezability as 24.29 and $7.29 \%$, respectively were most frequently observed in KF bulls ${ }^{24}$. The present study was done to investigate the disposal pattern of cattle born through ET and further compared with those through artificial insemination (AI). The trend was much higher in ET group, rather $100 \%$ without desired level of contribution, particularly as per cost output ratio.

Embryo transfer is an excellent tool for faster genetic gains and multiplication of superior animals. However, as still there remains complexity and high expenses, research is required especially in selection of donor and recipient animals. The technique of ET has become quite simple and acceptable and many good embryo transfer veterinarians, technicians and companies in general across the world are using this technology ${ }^{25}$.However, a few studies those were undertaken right from its inception have unfolded various serious genetic defects. It is still shadowed by the well documented adverse effects on the survival and wellbeing of the offspring. Increased prenatal, perinatal losses and physiological malfunctions have been reported to result due to growth factors in culture media and hormonal interventions (progesterone) at the time of superovulation ${ }^{26}$. During superovulation regimen, the quality of the embryo might be affected either through responsiveness of the oocyte or follicular growth ${ }^{27}$ or directly during embryo development while in the oviduct and/or uterus ${ }^{28,29,30}$.

In the last 35 years reproductive biotechnologies have expanded world-wide particularly in research institutes, universities or centres and are still continually evolving in most of the domestic animals. Embryo transfer has become the most powerful tool for scientists and breeders to improve genetic construction of their herds and increase quickly elite individuals for efficient and more profitable businesses. Investigations have focus on manipulations of pre-implantation embryos. However, understanding on embryonic early mortality and development is still relatively limited on many facts such as identifying embryo with distinct chance of survival for transfer, development, birth of normal offspring and its performance remains challenging. Several recent reviews on current status of ET 
have explained several problems and suggested for research on its potential benefit to international agricultural community ${ }^{31,32,33}$. The bovine industry remains the niche that uses extensively ARTs to propagate genetics.

In western countries the abnormal even dead calves or adult non-fertile animals are disposed immediately, may be to meat industry for pet food or other products. However, in Indian conditions such animals become burden to farms or farmers or even to society. Therefore in India it is very essential before the technique is applied on a larger and practical scale and biological aspects associated with ET must be taken into serious consideration otherwise it may lead to cytogenetical, epigenetic and physiological malfunctions in the new born calves. Observations also show that usually to get sure conceptions two or more number of embryos are placed in the uterus of recipients, which often lead to twin births and freemartins or poor producers. Hence to reduce the risk of multiple births only one embryo is to be transferred per cow, even at the cost of waste of cycle of the recipient. Moreover the studies on the disposal characteristics of bovines born through ET are scanty. It is further suggested that the performance and fate of the calves born through ET must be carried out by the users of this technique so that consequences of high culling rate and mortality due to abnormal and unwanted reasons can be avoided and loss of genetic pool is prevented.

\section{Conclusions}

The calves produced in the ET programme with significantly high cost and huge resources of the organization, and were considered a big achievement. The donor dams were superior females with milk yield above the herd average and semen was also used from proven bulls. The observations on the fate of these calves in this study revealed that most of them (40\%) did not reach the puberty stage/ age of breeding. However, those reached puberty and taken in breeding programme were culled on the basis of their poor performance. Similar phenomenon was observed in both the sexes. All the males failed to become bulls for use in AI programme. Only a few females entered in production herd and being progeny of superior parents, yield was comparable to better contemporaries; however, with poor resistance got bacterial infection and were disposed. The technique of ET has become quite simple and acceptable at world level; nevertheless, a large number of studies undertaken since its inception have shown many serious anomalies. Progenies have been produced in many organizations (institutes, universities and even farmers' herds) in India; however technology remains at limited level for personal reasons. Thus before the technique is applied on a large and practical scale, methodological and biological aspects associated with ET must be improved and made applicable like AI.The observations in the present investigation showed the performance of calves born through ET was quite poor and the techniques needs improvement.

\section{ACKNOWLEDGEMENT}

Authors are highly grateful to the Director, ICAR-NDRI for providing all the research facilities and financial grant of DBT is well acknowledged to the corresponding author.

\section{REFERENCES}

[1] Tibary, A., Campbell A. J. and Pearson L. K., Evolution of embryo transfer in domestic animals, Spermova, 3 (1), 1-9 (2013).

[2] Betteridge, K. J., Farm animal embryo technologies: Achievements and perspectives, Theriogenology, 65, 905-913 (2006).

[3] Desai, A., Shirode, A. R., Mittal, B. and Kadam V. J., Assisted reproductive technology (ART): Combating infertility, Asian J. Pharm. Clin.Res., 4, 18-22 (2011).

[4] Wu, B., Advances in Embryo Transfer, edited. Published by In Tech. Janeza Trdine Rijeka, Croatia, 2012, www.intechopen.com (Book).

[5] Galli, C., Duchi, R., Crotti, G., Turini, P., Ponderato, N., Colleoni, S., Lagutina, L. and Lazzari, G., Bovine embryo technologies, Theriogenology, 59, 599-616 (2003).

[6] Grimes, J.F., Utilization of Embryo Transfer in Beef Cattle. Agricultural and Natural Resources, (ANR17-08), The Fact sheet of Ohio State University,Pp: 1-5 (2008). (ohioline.osu.edu/anr-fact/pdf/ANR_ 17_08.pdf) 
[7] Schmidt, M., Greve, T., Avery, B., Beckers, J. F., Sulon, J. and Hansen, H. B., Pregnancies, calves and calf viability after transfer of in vitro produced bovine embryos, Theriogenology, 46, 527-539 (1996).

[8] Mapletoft, R. J., Steward, K. B. and Adams, G. P., Recent advances in the superovulation in cattle, Reprod. Nutr. Dev., 42, 601-611 (2002).

[9] Lonergan, P., State-of-the-art embryo technologies in cattle, Soc. Reprod. Fertil.Suppl.,64, 315-325 (2007).

[10] Jacobs, P. A. and King, W. A., The role of chromosome abnormalities in reproductive failure, Reprod. Nutr.Dev., 1, 63-74 (1990).

[11] King. W. A., Coppola, G., Alexander, B., Mastromonaco, G., Perrault, S., Nino-Soto, M. I., Pinton, A., Joudrey, E. M. and Betts, D. H., The impact of chromosome alteration on embryo development, Theriogenology, 65, 166-177 (2006).

[12] Williams, C. V. and Long, S. E., The effect of superovulation on the chromosome complement of early sheep embryos, Proc. 4th Eur. Collog. Cytogenet. Domest.Anim., Uppsala, Pp168-171 (1980).

[13] Roberts, R., Iatropoulou, A., Ciantar, D., Stark, J., Becker, D. L., Franks, S. and Hardy, K., Folliclestimulating hormone affects metaphase-I chromosome alignment and increases aneuploidy in mouse oocytes matured in vitro,Biol. Reprod., 72, 107-118 (2005).

[14] Young, L. E., Sinclair, K. D. and Wilmut, I., Large offspring syndrome in cattle and sheep, Rev. Reprod.,3, 155-163 (1998).

[15] Wilson, J. M., Williams, J. D., Bondioli, K. R., Looney, C. R., Westhusin, M. R. and McCalla, D. F., Comparison of birth weight and growth characteristics of bovine calves produced by nuclear transfer (cloning), embryo transfer and natural mating, Anim. Reprod. Sci.,38, 73-84 (1995).

[16] Walker, S. K., Hartwich, K. M. and Seamark, R. F., The production of unusually large offspring following embryo manipulation: concepts and challenges, Theriogenology, 45, 111-120 (1996).

[17] Viuff, D., Hendriksen, P. J. M., Vos, P. L. A. M., Dieleman, S. J., Bibby, B. M., Greve, T., Hyttel, P. and Thomson, P. D., Chromosomal abnormalities and developmental kinetics in in vivo-developed cattle embryos at days 2 to 5 after ovulation, Biol. Reprod., 65,204-208 (2001).

[18] Bishop, M.W., Paternal contribution to embryonic death,J. Reprod. Fertil.,7, 383-396 (1964).

[19] Callesen, H., Challenges in work with bovine gametes and embryos, Anim. Reprod.,9, 341-344 (2012).

[20] Maxfield, E. K., Sinclair, K. D., Dolman, D. F., Staines, M. E and Maltin, C. A., In vitro culture of sheep embryos increases weight, primary fibre size and secondary to primary fibre ratio in fetal muscle at day 61 of gestation, Theriogenology,47, 376 (1997).

[21] Schmidt, M., Perinatal death associated with ET, IVP and cloning in cattle, Acta Veterinaria Scandinavica, 49 (Suppl 1): S13 doi:10.1186/1751-0147-49-S1-S13 (2007).

[22] Singh, M. K. and M. Gurnani, Performance evaluation of Karan Fries and Karan Swiss cattle under closed breeding system, Asian-Aust. J. Anim. Sci., 17(1),1-6 (2004).

[23] Khatun, M., Kaur, S., Kanchan, and Mukhopadhyay, C. S., Subfertility Problems Leading to Disposal of Breeding Bulls,Asian-Aust. J. Anim. Sci.,26, 303-308 (2013).

[24] Mukhopadhyay, C. S., Gupta, A. K., Yadav, B. R., Khate, K., Raina, V. S., Mohanty, T. K. and Dubey, P. P., Subfertility in males: An important cause of bull disposal in bovines, Asian-Aust. J. Anim. Sci.,23(4), 450-455 (2010)

[25] Faber, D. C., Molina, J. A., Ohlrichs, C. L., Vander Zwaag, D. F. and Ferré, L. B., Commercialization of animal biotechnology, Theriogenology, 59, 125-138 (2003).

[26] Blanco, M. R., Demyda S., Moreno-Millán, M. and Genero, E., Developmental competence of in vivo and in vitro matured oocytes: A review, Biotechnol. Mol. Biol. Rev.,6, 155-165 (2011).

[27] Sirard, M. A., Richard, F., Blondin, P. and Robert, C., Contribution of the oocyte to embryo quality, Theriogenology, 65, 126-136 (2006).

[28] Barnes, F. L., The effects of the early uterine environment on the subsequent development of embryo and fetus, Theriogenology, 53, 649-658 (2000).

[29] Greve, T. and Callesen, H., Rendez-vous in the oviduct: implications for superovulation and embryo transfer, Reprod. Nutr.Dev.,41, 451-459 (2001). 
[30] Killian, G. J., Evidence for the role of oviduct secretions in sperm function, fertilization and embryo development, Anim. Reprod. Sci., 82,141-153 (2004).

[31] Genzebu. D., A Review of Embryo Transfer Technology in Cattle, Global Journal of Animal Scientific Research,3 (2), 562-575 (2015).

[32] Blondin, P., Status of embryo production in the world, Anim. Reprod.,12(3), 356-358 (2015).

[33] Makarevich, A., Kubovičová, E., Pivko, J., Olexiková, L., Bulla, J., Chrenek, P., Several key aspects of the research on bovine preimplantation embryos at the research institute for animal production (RIAP) in Niatra, The 3rd International Scientific Conference “Animal Biotechnology” Slovak J. Anim. Sci.,48 (4), 172-180 (2015).

Citation: V. Sah et al., "Disposal Pattern of Cattle Calves Born through Embryo Transfer Technology", International Journal of Research Studies in Biosciences (IJRSB), vol. 5, no. 9, p. 4-10, 2017. http://dx.doi.org/ 10.20431/2349-0365.0509002

Copyright: (C) 2017 Authors. This is an open-access article distributed under the terms of the Creative Commons Attribution License, which permits unrestricted use, distribution, and reproduction in any medium, provided the original author and source are credited. 